\section{In a Nutshell}

\section{Bechtel Scholar Studies Chapbooks, Sendak}

\author{
SUZI WACKERBARTH
}

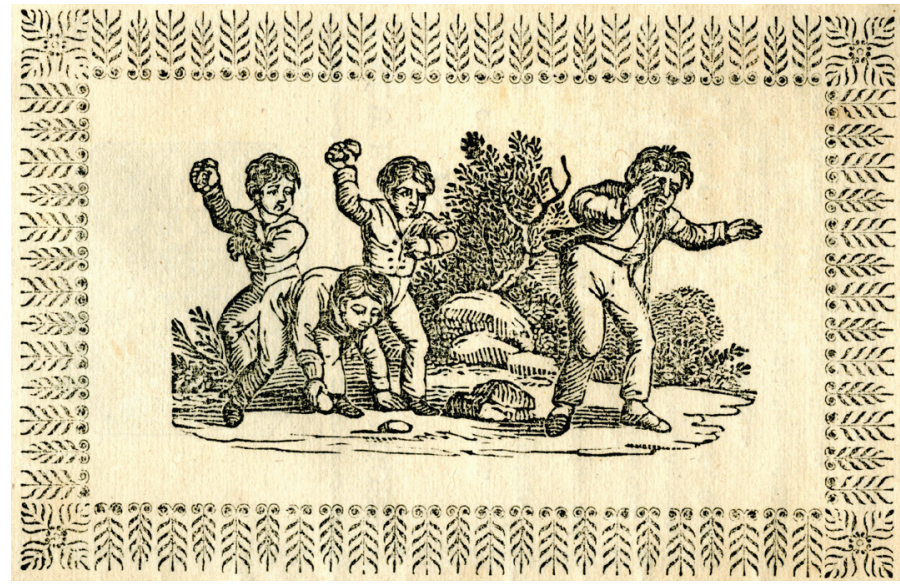

"Boys Bullying a Boy," from Lessons for Good Children, 1837. Photo used with permission from the Baldwin Library of Historical Children's Literature, George A. Smathers Libraries, University of Florida.

and contrast these titles with the books listed in the Baldwin's online catalog.

But that is not the article you are about to read. No, this is the story of how one librarian thought she was going to explore all sorts of questions and answers about manners from the eighteenth century to the twenty-first century and ended up learning about chapbooks and focusing on a few books by Maurice Sendak.

Start at the beginning? I'll try. On my third day at the University of Florida's Smathers Special Collections Library, I came across a tiny chapbook in a clear cellophane envelope, The Book of Manners for Girls and Boys. I was quickly charmed. Unlike earlier books and chapbooks on manners, books I had set aside saying, "no, not this," "no, not that," this tiny book told stories. It was not a book of proverbs or endless lists of instructions. The Baldwin collection owns two editions, 1843 and 1845, printed by Geo. P. Daniels in Providence, Rhode Island. Both books are illustrated with woodblocks common to any chapbook, not necessarily corresponding to the text. But the 1845 edition is hand colored. I did not know

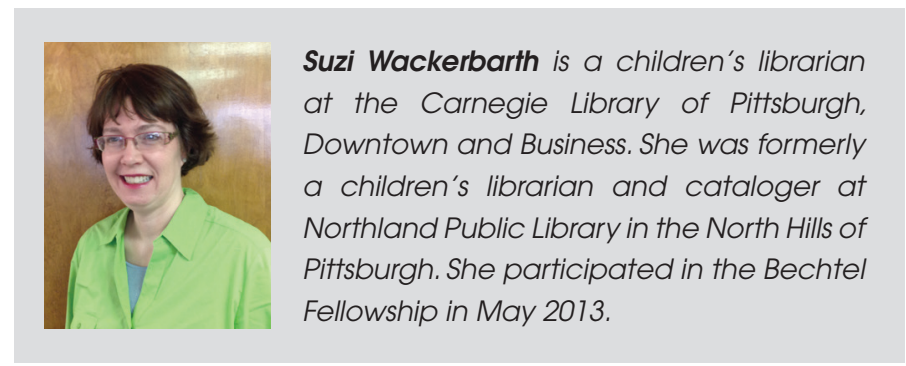


what I wanted to learn, just that I was delighted and a little bit in love.

What is a chapbook? The best definition I found comes from $A$ Book about Chapbooks: The People's Literature of Bygone Times by Harry B. Weiss:

\begin{abstract}
The term chapbook may include...anything printed-that was carried for sale by a chapman into villages, hamlets, towns. Although they varied in size, the small ones, as a rule, being intended for children...were about $5-1 / 2-$ by-3-1/2 inches and contained from four to twenty-four pages, but there was really nothing fixed about their size or about the number of their pages. ${ }^{2}$
\end{abstract}

Chapbooks were mostly published in the eighteenth and nineteenth centuries and were the books of the lower classes. This was a time when printed books were expensive and hard to come by. Libraries were still a new idea, and of course, no one had a Kindle. Chapmen (traveling peddlers) sold various things, including chapbooks. A lot of American chapbooks were directly plagiarized from British books or chapbooks. It was a different time in publishing, when having a printing press meant you could be a publisher. Copyright laws were lax and not a priority in the colonial times, and the ensuing early years of independence. Chapbooks were more often than not distinguished by their publishers than their authors, and the creators of the woodcut illustrations were not credited in any of the chapbooks I examined.

I wanted to know more about chapbooks, but information on this topic was not easily found. I wasn't interested in manners anymore. It wasn't necessarily the content that interested me-upon closer examination, charming in size as the chapbooks were, the best things about most of these books were the woodblock illustrations and borders. How to talk in company, how to help your parents, how to comport with your siblings-these books had as much subtlety as The Berenstain Bears and Too Much Birthday. This was not the sort of research I was interested in embarking any longer.

I had hit a wall in my research. And when that happens, I do three things: I take a walk, I continue to research, and I talk to teachers and librarians. I got to know the part of the University of Florida between my bus stop and the library, full of trees I was never able to name. I looked at books about illustration in children's books. I talked with the librarians who worked in the Special Collections building.

On my first Friday in Florida, I went to lunch at a nearby restaurant with Suzan Alteri, curator of the Baldwin Collection. We dined with my faculty advisor, Dr. John Cech. We talked about my research, and I mentioned that I wasn't sure where to take my new discovery of chapbooks, or where to go with my topic of manners. Cech is a Maurice Sendak scholar, and somewhere along the way, the conversation moved to the topic of Sendak and then to a television special from the seventies, "Really Rosie," in which some of Sendak's books, including the four titles that make up his Nutshell Library, were animated and put to music. I shared that while I had never seen the show, my grandmother had given me the soundtrack album as a present, and to this day, the songs are easily accessed by my memory.

I came away from lunch with more questions than answers, but I requested everything the Baldwin Library owned by Sendak. I worked my way through his first solo book, Kenny's Window, read again through the twin Joslin (What Do You Say/ $D o$ ?) books, and revisited Where the Wild Things Are. Then I came across the Nutshell Library, a collection of four books in a mini slip case, just the right size for tiny hands $-33 / 4$ by 3 inches. As I held these four books, took them out of their snug slipcase, a light bulb went off in my head. But I hesitated. Was I crazy to see similarities between the American chapbooks and the Nutshell Library?

I did some more research, asked Cech, asked others who had studied or known Sendak, and herein lay the problem. No one could verify that Sendak had owned chapbooks (though we knew he owned many early American books). No one knew if he had chapbooks in mind when he wrote the Nutshell Library, and without that information, my research was $\mathrm{PhD}$ level work, not "Fellow for one month and back to being a librarian" level work.

Some of my initial observations about chapbooks: they were crowded with words, illustrations were well drawn, but seemed to be an afterthought and rarely had action. Lessons for Good Children in Easy Rhyme has many illustrations that do not match the text at all, of a child next to another child who seems to be falling out of a window, an image of a group of children wielding stones running after another child, and a small illustration of children carrying sticks, chasing a dog. What I noticed about the Nutshell Library: Pictures were either on their own page (Chicken Soup with Rice/Pierre) or illustrations dominated the page and text was minimal (Alligators all Around/One was Johnny). Chapbooks, even the ones that were called "toy books," were full of morality.

On the other hand, Sendak's words and illustrations have always emphasized children as they were, and fun is tantamount. Sendak's words on illustration: "You must never illustrate exactly what is written. You must find a place in the text so the pictures can do the work." ${ }^{3}$

Before I knew it, it was October; I was back in Pittsburgh, and it was time to write my report to the University of Florida about my fellowship. Hoping for some answers, I pulled out my personal copy of Dear Genius: The Letters of Ursula Nordstrom, collected and edited by Leonard Marcus, turned to the index in the back, and there, under the Sendak citations was a citation for Nutshell Library. I turned the pages, and there it was, proof! At the bottom of page 154, the second footnote reads,

MS collected eighteenth- and early-nineteenth-century children's chapbooks, the characteristically small format of 
which appealed to him as being well suited to young children's hands. The didactic content of the books was another matter. MS saw Nutshell Library as a chance to stand the moralistic children's literature of the past on its head. ${ }^{4}$

This was the missing link I had been looking for, textual proof that Sendak was familiar with chapbooks! I could research the style and form of American chapbooks and Sendak's Nutshell Library. I could eschew the study of manners!

While the footnote is the only textual proof that I have that Sendak owned chapbooks, there are many hints in his words and illustrations that point to his knowledge of the format. I did not e-mail Leonard Marcus to find out how he knew that Sendak owned chapbooks, or how he knew about Sendak's intent to "stand the moralistic literature of the past on its head." ${ }^{5}$

So I do not know which chapbooks Sendak owned, or which ones he referred to as he put together the Nutshell Library. Knowing that Sendak found chapbooks appealing, I'd like to think that he looked at them, crude and moralistic as they were, with the same eyes that he looked at the cheap books he grew up with. In Artist to Artist, he writes about “...the books I loved-those cheap, pulp-papered, gorgeously if vulgarly colored comic books and story books." ${ }^{6}$ Armed with this footnote, this tiny piece of information, I offer my observations from three books of Sendak's and discuss similarities and differences with chapbooks that I examined while at the Baldwin Library.

The first Sendak book I want to discuss is not in the Nutshell Library, but it is the earliest example I noticed of the chapbook's influence in his books. Published in 1957, it is the first book in the Little Bear "I Can Read" series by Else Holmelund Minarik, Little Bear. In almost every chapbook I examined, printers used a stylized woodcut frame or border around full page illustrations and the front and back covers. Sometimes the border is made up of geometric shapes, sometimes it mimics frames seen in illuminated books of the Middle Ages. Flowers, vines, egg and dart patterns, rectangles, the variety used in even one single chapbook lacks rhyme or reason.

In Little Bear, Sendak uses this woodblock style border around the text and illustrations on each page. Three times in the book, Sendak plays with the border: on the title page, where Little Bear hangs off it like a vine; on page 23, where fruits and vegetables grow off it; and on page 39, where Little Bear hangs on it, wearing his new space helmet. This woodblock style border only appears in the first Little Bear book.

Here I'll compare four books: two chapbooks and two books from the Nutshell Library. First, let me introduce you to a chapbook called The School of Good Manners, which I will compare to Alligators All Around. The School of Good Manners exists in many formats, both in British and American chapbooks, with varying contents and lengths. The School of Good Manners was not intended for children, but "composed for

\section{American Chapbooks Studied at the Baldwin Library}

Book of Good Manners (Providence: George Daniels, 1843, 1845). Stories about boys and girls that illustrate good manners. This was the book that started my research. A woodcut of a sofa illustrates the section about parlor manners. A picture of a cow is featured on the inside cover of the 1843 edition. In the same space in the 1845 edition, a picture of a bird is featured.

Boys/Girls Picture Book (Concord, N.H.: Rufus Merrill, 1843). Boy's book has more pictures (front/back inside cover) and more action. "See this book being carried by a boy. Large load for a small boy." Girl's book is more moralistic, less action. "Good children will not hurt birds. It is very wicked to destroy birds' nests."

Lessons for Good Children (New Haven: S. Babcock, 1837). Plagiarized from the 1835 British book, Pretty Lessons in Verse, for Good Children; with some lessons in Latin, in easy rhyme by Sara Coleridge.

School of Good Manners, 1754, which contains "An Alphabet of useful copies."

School of Good Manners, 1802. The Baldwin's copy is falling apart not just from age, but from use. At least one child used the book as writing practice.

Wisdom in Miniature: 1807, 1818. Fascinating to look at the two editions side by side: the woodcuts are printed opposite in each edition.

Digitized chapbooks in the Baldwin Library can be found at the following address: http://ufdc.ufl.edu/ baldwin/results/? $†=$ chapbooks

the help of parents in teaching their children how to carry it in their places during their minority."7

The English is archaic and unclear, but I take the meaning as this: it is a handbook for parents in teaching manners to their children. In the 1754 version, published by T\&J Green, there is a chapter called "An alphabet of useful copies." It is not an alphabet in the sense of "A is for apple" but more an acrosticthe first letter of each sentence starts with a letter of the alphabet, in order, a style found in ancient Hebrew poetry found in the Old Testament Psalms and Proverbs. Here is a sample from the "Alphabet of useful copies:"

Keep thyself humble, Pride has ruined many, The proud man's seldom well-belov'd of any.

Love covers multitude of faults, but hate Old faults discovers \& does new ones make. ${ }^{8}$ 
The writer is emphasizing humility and love. The rest of the alphabet talks about sin, revenge, lying, all things that should be avoided. Truth, patience, thinking, these are all to be lauded and encouraged. Placed side by side with the antics described in words and images in Alligators All Around, Sendak literally turns manners and comportment on their heads with " $U$ : Usually upside-down."

Sendak never wrote or illustrated a book about a sedate child who did what adults thought he should. The alligators are also Very Vain, Quite Quarrelsome, and Entertaining Elephants. Sendak does not comment on these states, does not admonish nor give advice. While the cover and verso page illustrations are both of the alligator family holding up letters of the alphabet in the appearance of learning something, "B bursting balloons" bursts our bubble of the well-mannered child. Hilarity and non-conformity by both parents and children continue through the rest of the alphabet. In his writings about Alligators All Around, Sendak says, "The least important aspect of Alligators is that it is an alphabet. . .my alligators aren't teachers. . .they stick their tongues out, stand upside down, and are very vain. They do the kind of things all my children do."

While The School of Good Manners was written for parents, many chapbooks were billed (on their back covers, with more titles you could obtain) as "toy books." One of these was Lessons for Good Children, In Easy Rhyme, which explores three topics: the days of the week, the months of the year, and the seasons. This was the book that made me think of similarities between the Nutshell Library and the American chapbooks. Here is some verse from a poem about the months:

January brings the snow, makes our feet and fingers glow. February brings the rain, thaws the frozen lakes again. ${ }^{10}$

These couplets are written as if they are meant for children to actually enjoy them, not just written for instructive purposes. However, the days of the week, listed earlier in the chapbook, are full of the morality and dread often found in early attempts at books for children:

$$
\begin{aligned}
& \text { On Sunday begin } \\
& \text { The week without sin; } \\
& \text { On Monday resume } \\
& \text { Your tasks without gloom; } \\
& \text { And pray dont be vex'd } \\
& \text { That Tuesday comes next; }{ }^{11}
\end{aligned}
$$

The reader learns the days of the week, but also reminded that life is gloomy and full of sin. In contrast, Chicken Soup with Rice, Sendak's book of months, is full of fun and fantasy.

Let's look at it from the start, though. At onset, from the book's cover, Chicken Soup with Rice looks tame enough—a boy holding a bowl of chicken soup and a spoon. The t.p. verso indicates that perhaps the book will have some fantasy elements, as the person eating soup with the boy looks like a goblin. But open to January, and we have a sweet boy, eating chicken rice while ice skating on a lake. Turn the page, though, and fantasy has taken over. The boy is sharing a meal with a snowman, and though seated indoors, the snowman is not melting. The months continue, with the boy sharing his soup with the wind in March, an elephant in April. In May, the boy has turned into a robin, and the soup is being stirred in a nest.

My favorite is August, where “...it will be so hot/I will become/a cooking pot/cooking soup of course./Cooking once/cooking twice/cooking chicken soup/with rice." ${ }^{12}$ The reader certainly learns the months, but fantasy and fun are mixed in.

What I have done here is merely introduce chapbooks and how they compare to a few Sendak books. I've listed below some of the chapbooks I looked at in detail while at the Baldwin Library. I hope in years to come to spend some more time studying these fascinating booklets, and I hope I have piqued your interest as well.

\section{References}

1. Susan Dove Lemke, "What Makes a Good Manners Book?" Horn Book 88 (Sept./Oct. 2012): 32-38.

2. Jeremiah Post, "Review of A Book about Chapbooks: The People's Literature of Bygone Times by Harry B. Weiss," RQ 10, no. 2 (Winter 1970): 169, www.jstor.org/ stable/25824107, accessed Aug. 15, 2014.

3. The Eric Carle Museum of Picture Book Art, Artist to Artist: 23 Major Illustrators Talk to Children about Their Art (New York: Philomel, 2007), 74.

4. Leonard Marcus, ed., Dear Genius: The Letters of Ursula Nordstrom (New York: HarperCollins, 1998), 154.

5. Ibid.

6. The Eric Carle Museum of Picture Book Art, Artist to Artist, 74.

7. School of Good Manners (Haverhill, N.H., Haverhill,1802), t.p.

8. “Alphabet of Useful Copies," School of Good Manners (New London, Conn.: T\&J Green, 1754), 77.

9. Selma Lanes, The Art of Maurice Sendak (New York: Abrams, 1980): 71-72

10. S. Babcock, Lessons for Good Children, in Easy Rhyme (New Haven: S. Babcock, 1837): 5.

11. Ibid., 3 .

12. Maurice Sendak, Chicken Soup with Rice (New York: HarperCollins, 1962), 20. 